UDC: $616.12-008.331 .1+616.379-008.64]-056.52-092: 612.018$

\title{
COMPARISON OF HIGH-FAT AND HIGH-CARBOHYDRATE DIETS FOR OBTAINING AN EXPERIMENTAL MODEL OF METABOLIC SYNDROME
}

\author{
T. S. Petryn ${ }^{\circledR}{ }^{*}$, M. R. Nagalievska®, N. O. Sybirna ${ }^{\circledR}$ \\ Ivan Franko National University of Lviv, 4 Hrushevskyi St., Lviv 79005, Ukraine \\ *Corresponding author e-mail: tetiana.petryn@Inu.edu.ua
}

Petryn T.S., Nagalievska M.R., Sybirna N.O. Comparison of high-fat and high-carbohydrate diets for obtaining an experimental model of metabolic syndrome. Studia Biologica, 2021; 15(1): 3-14 - DOI: https://doi.org/10.30970/sbi.1501.642

Introduction. Metabolic syndrome is a cluster of metabolic abnormalities that includes hypertension, central obesity, insulin resistance and atherogenic dyslipidemia. Given the wide geographical distribution and growing number of people suffering from this disease, there is an urgent need in developing animal models that would accurately reproduce the development of all symptoms of human metabolic syndrome (insulin resistance, dyslipidemia, obesity and hypertension). The most cost-effective method related to the real causes of metabolic syndrome is the use of different types of diets.

Materials and Methods. The study was performed on white outbred male rats about 6 months old and weighing 300-400 g. The metabolic syndrome was induced by highfat and high-carbohydrate diets. The lipid-enriched diet involved the consumption of regular chow diet for laboratory animals with additional fat content ( $40 \%$ by weight of chow). The source of additional lipids was olive oil, which is rich in monounsaturated fatty acids (MUFAs). Animals on the diet enriched in carbohydrates together with regular chow diet for laboratory animals consumed $10 \%$ fructose solution instead of drinking water. Glucose tolerance tests were conducted and areas under the glycemic curves were calculated. We determined the content of glycated hemoglobin and glucose concentration, the concentration of low-density lipoproteins (LDL), high-density lipoproteins (HDL), triglycerides and cholesterol in the blood plasma of rats.

Results. The development of metabolic syndrome induced by an excessive consumption of carbohydrates and lipids for 42 days was accompanied by impaired glucose tolerance, increased glycosylated hemoglobin, triglycerides and cholesterol concentrations, as well as a decreased HDL content. An increase in the concentrations of LDL and activity of paraoxonase were found due to the induction of the pathological condition by an excessive fat intake, while a high carbohydrate diet caused a decrease in paraoxonase activity.

( 2021 T. S. Petryn et al.; Published by the Ivan Franko National University of Lviv on behalf of Біологічні Студії / Studia Biologica. This is an Open Access article distributed under the terms of the Creative Commons Attribution License (http://www.budapestopenaccessinitiative.org and Creative Commons Attribution 4.0 License), which permits unrestricted reuse, distribution, and reproduction in any medium, provided the original work is properly cited.

ISSN 1996-4536 (print) • ISSN 2311-0783 (on-line) • Біологічні Студії / Studia Biologica • 2021 • Том 15 / № 1 • С. 3-14 
Conclusions. The use of fructose for 42 days causes the most pronounced manifestations of the studied pathology. The use of this model will allow determining the biochemical and molecular changes that accompany the development of this pathological condition. It will also facilitate the development and evaluation of the effectiveness of new therapeutic approaches to the treatment of metabolic syndrome.

Keywords: metabolic syndrome, diet-induced obesity models, hyperglycemia, dyslipidemia

\section{INTRODUCTION}

Metabolic syndrome (MetS) is a cluster of metabolic abnormalities that includes hypertension, central obesity (accumulation of fat in the abdominal area), insulin resistance and atherogenic dyslipidemia. MetS is closely associated with an increased risk of cardiovascular disease [5]. The wide geographical prevalence of this disease and an increasing number of patients with MetS in the developing countries emphasize the role of the quality of life in the development of this pathological condition. Such factors as the consumption of excess calories and lack of physical activity are believed to be the main causes of MetS.

There is an urgent need for developing animal models of MetS that would accurately reproduce the development of all symptoms of human metabolic syndrome (insulin resistance, dyslipidemia, obesity and hypertension). Modern approaches to modeling this pathological condition are based on the use of manipulations with the diet of animals (high-fat, high-carbohydrate diets or their combinations), the use of genetically modified animals (Zucker fatty (ZF), Zucker diabetic fatty (ZDF), DahIS.Z-Leprfa/Leprfa (DS/obese), Goto-Kakizaki (GK)), as well as the use of various chemicals for the induction of the pathological condition (glucocorticoids, antipsychotic drugs) [19]. Taking into account the vast amount of literature data on methods of modeling MetS, it is advisable to compare the effectiveness of different methods that can be used to induce this pathological condition. The most cost-effective method related to the real causes of MetS is the use of different types of diets.

The aim of the study was to select the optimal model of induction of MetS in rats based on the assessment of change of individual indicators of carbohydrate metabolism and lipid profile in the plasma of rats' blood.

\section{MATERIALS AND METHODS}

The study was performed on white outbred male rats about 6 months old and weighing $300-400 \mathrm{~g}$. The animals were kept in the vivarium of Ivan Franko National University of Lviv in clean and dry polypropylene cages under controlled temperature of $25 \pm 2{ }^{\circ} \mathrm{C}$, relative humidity of $45-55 \%$ and a 12-hour cycle of darkness/light. Animals were kept on the diet recommended for this species. Rats were acclimatized to the environment for 7 days before any experimental manipulations. 12 hours before and during the experiment, the animals did not have access to food. Animal health was constantly monitored. The protocol was conducted in compliance with the general ethical principles of animal experiments in accordance with the "General Principles of Work on Animals", approved by the Ist National Congress of Bioethics (Kyiv, Ukraine, 2001) and conforming the guidelines from Directive 2010/63/EU of the European Parliament on

ISSN 1996-4536 (print) • ISSN 2311-0783 (on-line) • Біологічні Студії / Studia Biologica • 2021 • Том 15 / № 1 • С. 3-14 
the protection of animals used for scientific purposes and the Law of Ukraine "On Protection of Animals from Cruelty" from February 26, 2006, as well as approved by the Ethics Committee of Ivan Franko National University of Lviv, Ukraine (protocol No. 14-01-2021 from January 5, 2021).

The experimental animals were divided into five groups: 1) control animals that consumed regular chow diet for laboratory animals (fat content $6.0-6.3 \%$ of total weight) (Control); 2) animals that consumed a lipid-enriched diet for 28 days (MetS $+\mathrm{O}_{28}$ ); 3 ) animals that consumed a lipid-enriched diet for 42 days (MetS $\left.+\mathrm{O}_{42}\right)$; 4 ) animals that consumed a carbohydrate-enriched diet for 28 days (MetS $+F_{28}$ ); 5) animals that consumed a carbohydrate-enriched diet for 42 days (MetS $+F_{42}$ ).

The lipid-enriched diet involved the consumption of regular chow for laboratory animals with addition of extra fat content ( $40 \%$ by weight of feed). The source of additional lipids was olive oil, where the content of monounsaturated fatty acids exceeds $65 \%[3,8]$. Animals on the diet enriched in carbohydrates other than standard food for laboratory animals consumed $10 \%$ fructose solution instead of drinking water [16].

Animal body weight was monitored on the $7^{\text {th }}, 14^{\text {th }}, 21^{\text {st }}, 28^{\text {th }}, 35^{\text {th }}$ and $42^{\text {nd }}$ days of the experiment. The glucose tolerance test was performed on the $28^{\text {th }}$ and $42^{\text {nd }}$ days of the experiment, whereupon the animals were removed from the experiment.

Glucose concentration was determined by glucose oxidase method using the analytical kit for enzymatic determination of blood glucose "Philisit-Diagnostics" [4].

Glucose tolerance test was performed in the morning after an 18-hour fasting of the animals. Before and after glucose loading, blood was taken from the tail vein of rats for analysis and used to determine glucose concentration. Based on the obtained data, we constructed a glycemic (sugar) curve that shows how quickly rats organisms absorb glucose (fasting - 0 point and 10, 20, 30, 40, 50, 60 min after glucose intake).

The integrated indicator of the area under the glycemic curves (AUCglu) was calculated using the trapezoid rule [20].

The content of glycosylated hemoglobin (HbA1c) in erythrocytes was determined by the colorimetric method. This method is based on the acid hydrolysis of the ketoamine bond in the presence of oxalic acetic acid. 5-oxymethylfurfural is formed as a result of this reaction. This compound reacts with 2-thiobarbituric acid (TBA). The result of this interaction is the formation of a colored complex, whose intensity is determined on the spectrophotometer [4].

Lipid profile was analyzed using commercial kits of reagents „Phyllisit-Diagnostics”. Plasma cholesterol level determination method is based on the cleavage of cholesterol esters with the subsequent formation of a colored compound of quinoneimine [21].

The method of triglycerides content determination is based on the cleavage of triglycerides by lipase with the formation of free fatty acids and glycerol. Hydrogen peroxide is formed due to several transformations of glycerol. In the presence of 4-aminophenazone and 4-chlorophenol under the action of peroxidase, hydrogen peroxide is converted into a colored compound - quinoneimine [14, 21].

The content of LDL in blood plasma was determined using the masking reagent that protects cholesterol from LDL from the action of cholesterol esterase and cholesterol oxidase. After other forms of lipoproteins react, hydrogen peroxide is decomposed by catalase. At the second stage, cholesterol is released from LDL and, after a series of reactions, it can be detected colorimetrically $[21,14]$.

ISSN 1996-4536 (print) • ISSN 2311-0783 (on-line) • Біологічні Студії / Studia Biologica • 2021 • Том 15 / № 1 • С. 3-14 
Chylomicrons, very low density lipoproteins (VLDL) and LDL are precipitated when phosphotungstic acid is added to the test sample in the presence of magnesium ions. After centrifugation, only HDL remains in the supernatant. The concentration of HDL cholesterol is determined by enzymatic colorimetric method [21].

Paraoxonase activity was assessed by its paraoxonase activity using a 4-nitrophenyl acetate as a substrate. Paraoxonase catalyzes the cleavage of 4-nitrophenyl acetate to form a colored 4-nitrophenol, the amount of which was detected colorimetrically. Paraoxonase activity is expressed in U/L [16].

Statistical processing of the results was performed by a computer program Microsoft Excel XP using Student's $t$-test. The calculation of the main statistical parameters was performed on the basis of quantitative data obtained as a result of the study and is presented in the form of $\mathrm{M} \pm \mathrm{m}$ (arithmetic mean $-\mathrm{M}$, the standard deviation of the arithmetic mean $-m$ ). To assess the significance of the difference between the statistical characteristics of two alternative sets of data, we conducted one-way analysis of variance. The difference was considered significant at $p \geq 0.95$ (significance level $P<0.05$ ).

\section{RESULTS AND DISCUSSION}

Decreased physical activity and excessive consumption of fats and carbohydrates are the most important factors that contribute to the development of metabolic syndrome. Due to the increase in the amount of fat in the body, the size of adipocytes increases. These cells have an increased lipolytic capacity, resulting in a massive flow of free fatty acids (FFA) and adipokines directly into the portal vein of the liver. High concentrations of FFA inhibit the absorption of insulin by the liver tissue, leading to hyperinsulinemia and insulin resistance [10].

Obesity is one of the main criteria for diagnosing metabolic syndrome. In view of this, it is important to study the change in body weight of animals when using olive oil as a source of additional lipids (MUFAs) and fructose as a source of additional carbohydrates. We found a sharp increase in body weight of animals with metabolic syndrome on the $7^{\text {th }}, 14^{\text {th }}$ and $21^{\text {st }}$ days of the experiment (Fig. 1).

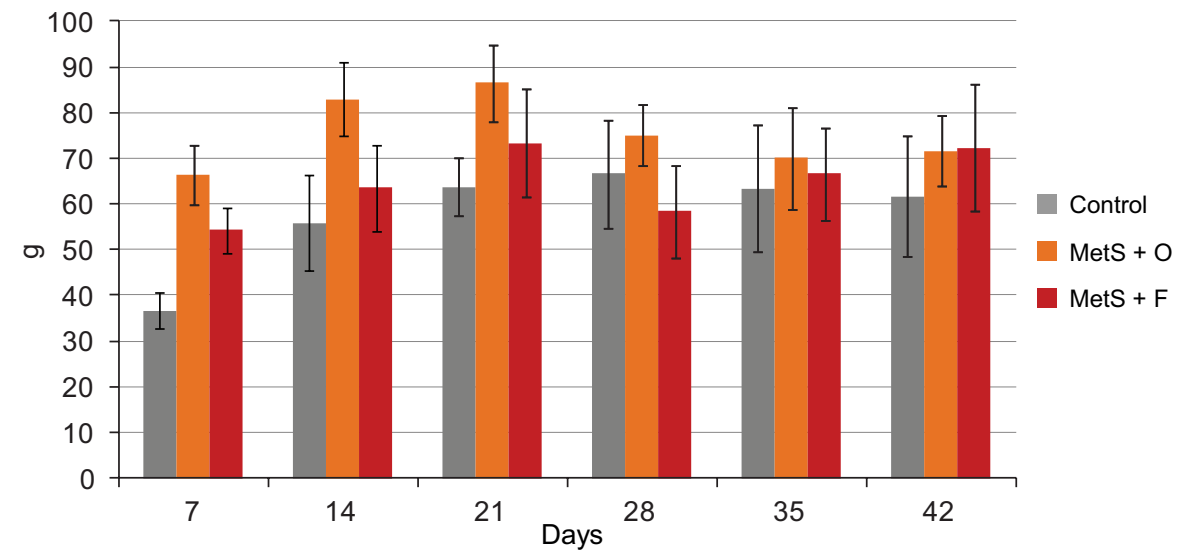

Fig. 1. Animal body weight gain in control animals and under conditions of diet-induced MetS (represented as a difference between the initial and current values of body mass)

Рис. 1. Маса тіла тварин у нормі та за умов дієт-індукованого метаболічного синдрому (представлена у вигляді різниці між вихідною і поточною масою тіла)

ISSN 1996-4536 (print) • ISSN 2311-0783 (on-line) • Біологічні Студії / Studia Biologica • 2021 • Том 15 / № 1 • С. 3-14 
Consumption of high-fat diet for one week was accompanied by an increase in body weight of rats by $27.4 \%$ relative to the body weight gain in the control group of animals. The second and third weeks of the diet was characterized by an increase in body weight by $29.6 \%$ and $35.6 \%$, respectively. On the $28^{\text {th }}, 35^{\text {th }}$ and $42^{\text {nd }}$ day of the experiment, the body weight of the experimental group of animals increased by $19.0 \%$, $10.8 \%$ and $10.7 \%$, respectively, compared with the control group.

Animal body weight increased by $16.4 \%$ during the first week of fructose intake, relative to the control. During the second and third weeks of experiment, body weight in the group of animal that consumed an extended amount of carbohydrates rose by $15.7 \%$ and $15.0 \%$, respectively. Further fructose consumption was not accompanied by a significant increase in the bodyweight of animals. The decrease in weight gain of animals at the terminal stages of the experiment may be due to a less pronounced intensity of pathological changes or activation of the body's adaptive mechanisms.

As one of the indicators of changes in carbohydrate metabolism, the efficiency of assimilation of exogenous glucose was evaluated. After intraperitoneal administration of glucose at a dose of $1 \mathrm{~g} / \mathrm{kg}$ of body weight, it was found that in control animals on the $10^{\text {th }} \mathrm{min}$ of the experiment, the carbohydrate content increased by $56.8 \%$. At the $20^{\text {th }}$ minute, a maximum increase in blood glucose (by $91.7 \%$ relative to the baseline) was shown. It was followed by a drop in glucose level $\left(30^{\text {th }} \mathrm{min}\right)$, with next reduction of its concentration to the baseline level (Fig. 2).

A

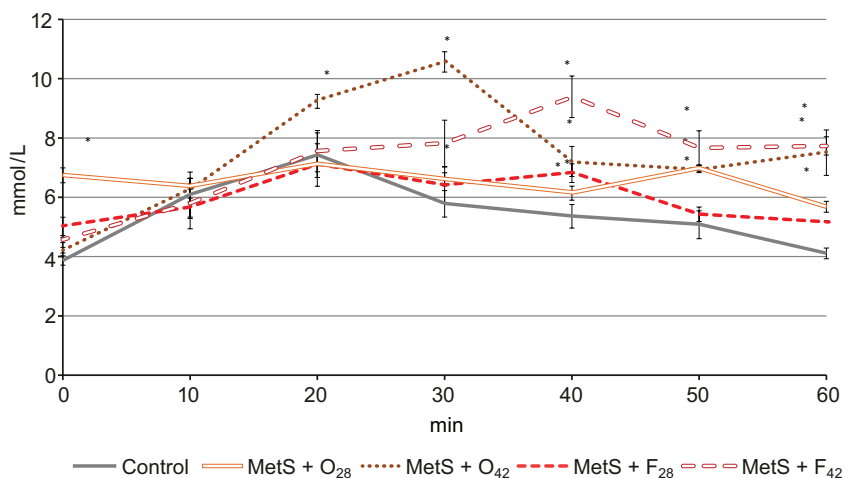

$B$

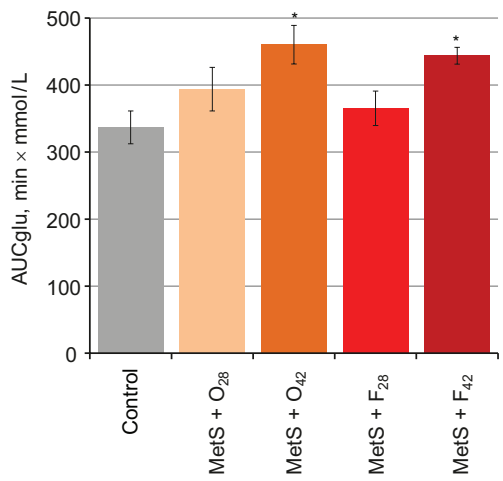

Fig. 2. Glycemic curves under the condition of lipid-induced and carbohydrate-induced MetS $(\boldsymbol{A})$ and the area under glycemic curves $(B)(M \pm m, n=4-8)$.

Comment: hereinafter * - the difference is significant compared to the control, $\mathrm{P}<0.05$

Рис. 2. Глікемічні криві за ліпід-індукованого й вуглевод-індукованого метаболічного синдрому $(\boldsymbol{A})$ та площі під глікемічними кривими (B) $(\mathrm{M} \pm \mathrm{m}, \mathrm{n}=4-8)$.

Примітка: тут і далі * - різниця вірогідна порівняно з контролем, $\mathrm{P}<0,05$

Our results show that lipid-induced MetS was accompanied by significant changes in the intensity of glucose uptake (Fig. 2A). In animals that consumed high-fat diet for 28 days the maximum increase in glucose concentration after administration of exogenous glucose was observed on the $20^{\text {th }}$ min of the experiment, and in animals that were on diet for 42 days - on the $30^{\text {th }} \mathrm{min}$. In animals that consumed excessive amounts of fat for 28 days, the glycemic curve was linear due to the lack of fluctuations in glucose 
levels. Instead, a longer induction of metabolic syndrome by fats caused more significant changes in the glycemic curve (Fig. 2A). An increase in AUCglu by $36.6 \%$ relative to the control indicates a more pronounced impairment of glucose tolerance in the case of induction of metabolic syndrome by consuming a high-lipid diet for 42 days (Fig. 2B).

Following a high-carbohydrate diet was also accompanied by impaired glucose tolerance, as indicated by the shift of the glycemic peak to the $40^{\text {th }} \mathrm{min}$, relative to such a peak in the control animals on the $20^{\text {th }}$ min (Fig. $2 A$ ). It should be noted that a more pronounced violation of the assimilation of exogenous glucose was typical for animals that consumed a fructose solution for 42 days. In particular, an increase in AUCglu by $8.4 \%\left(\mathrm{MetS}+\mathrm{F}_{28}\right.$ ) and significant increase by $31.7 \%$ (MetS $+\mathrm{F}_{42}$ ), relative to control (Fig. 2B) was found.

The main diagnostic criterion for the development of insulin resistance is an impaired glucose tolerance with the corresponding development of hyperglycemia and an increase in glycosylated hemoglobin concentration. $\mathrm{HbA} 1 \mathrm{c}$ is considered as a good marker for assessing glycemic conditions since it reflects a time-weighted mean over the previous 3 to 4 months and is an adequate predictor of complications [17].

It was found that the high-fat diet was accompanied by a significant increase in glucose concentration by $74.0 \%$ (MetS $+\mathrm{O}_{28}$ ) and an upward trend by $9.0 \%$ (MetS $+\mathrm{O}_{42}$ ), relative to control. The increase in glucose concentration leads to a significant increase in the content of glycosylated hemoglobin by $37.2 \%$ (MetS $+\mathrm{O}_{28}$ ) and $66.2 \%\left(\mathrm{MetS}+\mathrm{O}_{42}\right.$ ), relative to animals that consumed regular chow for laboratory rats (Fig. 3).

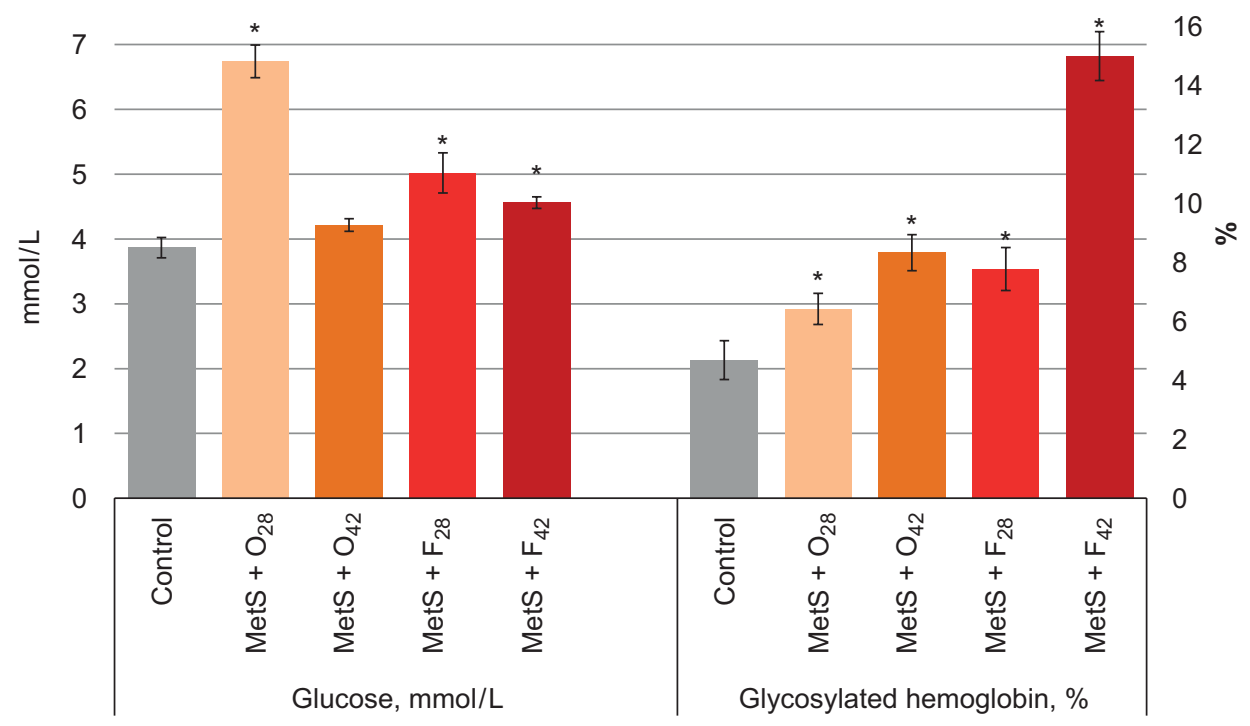

Fig. 3. Changes in glucose concentration and glycosylated hemoglobin content in control animals and under the condition of diet-induced MetS

Рис. 3. Зміна концентрації глюкози та вмісту глікозильованого гемоглобіну в нормі та за дієт-індукованого метаболічного синдрому

It is known that insulin increases the absorption of glucose by muscle and liver cells, as well as inhibits lipolysis and hepatic gluconeogenesis. In view of this, we can

ISSN 1996-4536 (print) • ISSN 2311-0783 (on-line) • Біологічні Студії / Studia Biologica • 2021 • Том 15 / № 1 • С. 3-14 
assume that the consumption of a lipid-rich diet leads to the development of insulin resistance, disruption of insulin signaling pathways, which ultimately leads to an intensification of lipolysis. The higher intensity of lipid breakdown causes an increase in the amount of FFA, which after their metabolism are additional substrates of gluconeogenesis. This causes an increase in blood glucose levels [18]. The established changes in carbohydrate metabolism can also be explained by an increased and prolonged exposure to high concentrations of FFA, which leads to a suppression of insulin secretion.

Using of fructose-rich diet was accompanied by a moderate increase in blood glucose concentration by $30.0 \%$ (MetS $+F_{28}$ ) and $17.8 \%\left(\right.$ MetS $\left.+F_{42}\right)$. However, we found a significant increase in glycosylated hemoglobin by $66.2 \%$ (MetS $+F_{28}$ ) and $220.5 \%$ $\left(\mathrm{MetS}+\mathrm{F}_{42}\right.$ ), compared with the control values (Fig. 3).

An excessive consumption of fructose leads to an increased absorption of this monosaccharide by liver cells. In these cells, fructose is converted to fructose-1-phosphate in a reaction catalyzed by the enzyme fructokinase in the presence of ATP. The next step is the cleavage of fructose-1-phosphate into glyceraldehyde and dihydroxyacetone phosphate. The breakdown of fructose into two trioses occurs without the conversion of glucose to fructose-1,6-bisphosphate in the initial regulatory stages of glycolysis. This bypass of the regulatory stages of glycolysis allows fructose to enter the glycolytic pathway continuously. All fructose entering the cell is rapidly metabolized to acetyl-CoA. When the cell is sufficiently supplied with energy, acetyl-CoA does not enter the tricarboxylic acid cycle, but is used for the synthesis of fatty acids. At this stage, fructose is involved in several simultaneous processes: (a) part of the fructose is converted from pyruvate to lactate, (b) the rest of the fructose is a source of triose phosphates, which are easily converted to glucose or glycogen during gluconeogenesis, (c) carbon atoms of fructose can be used for the synthesis of fatty acids and (d) the inhibition of hepatic lipid oxidation under conditions of high fructose concentration promotes the synthesis of VLDL and triglycerides and the transesterification of fatty acids [2].

An increase in the level of free fatty acids leads to increased synthesis of triglycerides and the formation of triglyceride-rich VLDL in the liver. An increase in LDL cholesterol and a decrease in HDL cholesterol are indirect effects of insulin resistance [15]. Under conditions of hyperinsulinemia and decreased sensitivity to insulin in adipose tissue, an increase in lipolysis and an increase in the supply of FFA to the liver takes place. This leads to an increase in the production of LDL, hypertriglyceridemia and a decrease in the content of HDL [11].

At evaluating the effectiveness of different diets for the induction of MetS, it is appropriate to establish their effect on the lipid profile of blood plasma. An increase in the concentration of plasma triglycerides was found in animals consuming a high-fat diet by $44.0 \%$ (MetS $+\mathrm{O}_{28}$ ) and $99.0 \%$ (MetS $+\mathrm{O}_{42}$ ), relative to the control. Similar changes were found in excessive carbohydrate intake by $42.6 \%$ (MetS $+F_{28}$ ) and $116.0 \%$ $\left(\mathrm{MetS}+\mathrm{F}_{42}\right.$ ) relative to the control values (Fig. 4).

An increase in the concentration of triglycerides correlates with the established increase in body weight of animals, due to the fact that triglycerides are a form of fat storage [6]. Such changes may also be associated with dysfunction of adipose triglyceride lipase (ATGL) - regulatory enzyme of lipid metabolism. ATGL is a major lipase in the liver and plays a crucial role in the hydrolysis of triacylglycerides in other tissues such as adipose tissue, heart and muscle. It was confirmed that the absolute ATGL inhibition leads to almost complete blockage of triglycerides hydrolysis [13]. 


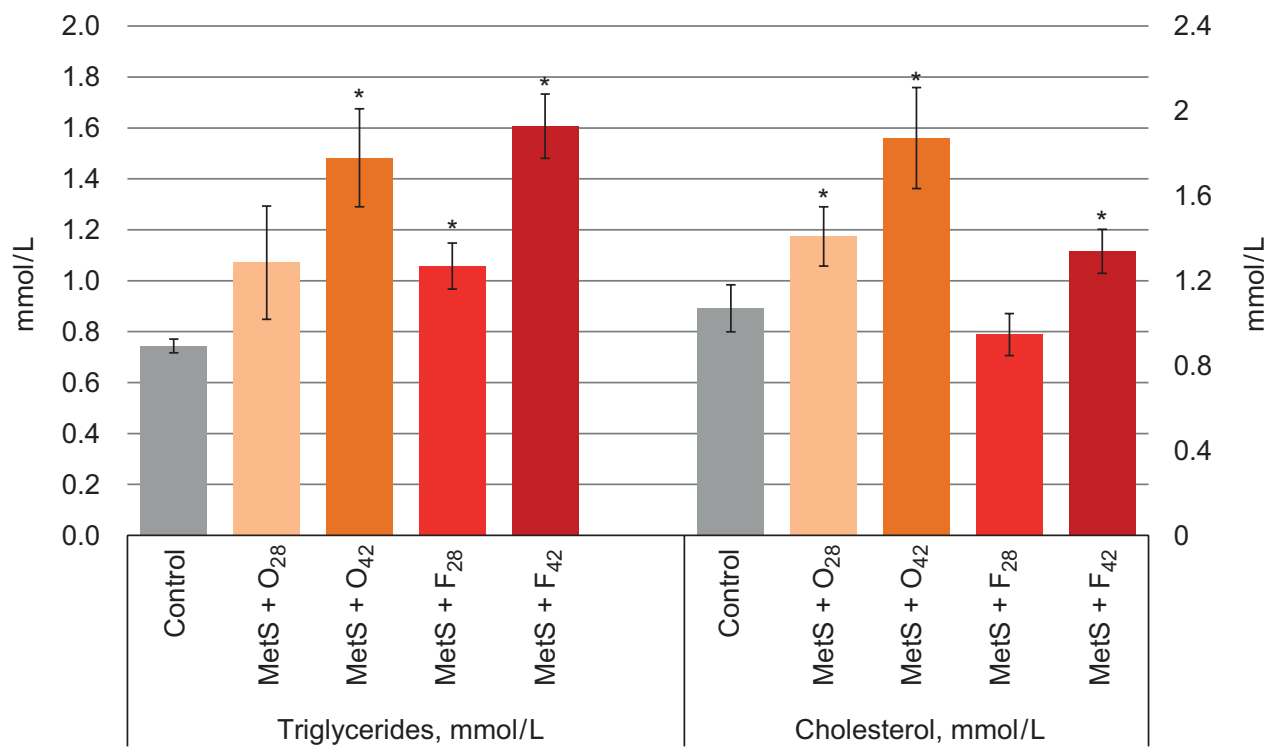

Fig. 4. Changes in triglycerides and cholesterol concentration in control animals and under the condition of diet-induced MetS

Рис. 4. Зміна концентрації тригліцеридів і холестеролу в нормі та за дієт-індукованого метаболічного синдрому

The development of MetS induced by 28 days consumption of high-fat diet was characterized by a significant increase in cholesterol concentration by $31.7 \%$. A longer period of induction caused $75.0 \%$ elevation of cholesterol concentration, compared to the control. Instead, consumption of fructose was not accompanied by significant changes in the studied parameter on the $28^{\text {th }}$ day of the experiment, while on the $42^{\text {nd }}$ day there was a $25.1 \%$ increase in cholesterol concentration (Fig. 4).

Application of the selected approaches to diet manipulation was accompanied by a decrease in HDL concentration by $30.7 \%$ (MetS $+\mathrm{O}_{28}$ ) and $35.0 \%$ (MetS $+\mathrm{F}_{28}$ ), with a longer induction of the pathological condition - by $18.0 \%$ (MetS $+\mathrm{O}_{42}$ ) and $40 \%$ $\left(\right.$ MetS $\left.+\mathrm{F}_{42}\right)$ (Fig. 5).

It was determined that the concentration of LDL in lipid-induced metabolic syndrome increased significantly by $36.6 \%$ (MetS $+\mathrm{O}_{28}$ ) and by $51.2 \%$ (MetS $+\mathrm{O}_{42}$ ), relative to the control values. This indicator decreased in animals on a high-carbohydrate diet by $20.6 \%$ (MetS $+F_{28}$ ) and a tendency to increase its concentration by $7.0 \%$ $\left(\mathrm{MetS}+\mathrm{F}_{42}\right.$ ) was also estimated.

Under conditions of elevated plasma triglycerides, CETP (cholesteryl ester transfer protein) is activated, which mediates the exchange of cholesterol and triglyceride esters between LDL. Similar lipid exchange occurs between VLDL and HDL particles, and this promotes the formation of HDL with a high content of triglycerides. HDL, which is rich in triglycerides but depleted in cholesterol, is more prone to catabolization. Next, their triglyceride component is hydrolyzed and their protein component, apo A (main HDL protein), dissociates. There are other additional mechanisms that contribute to the reduction of cholesterol HDL. For instance, an altered flow of lipids in the liver, which is due to insulin resistance, can be accompanied by a reduced production of apo A protein in the liver [11].

ISSN 1996-4536 (print) • ISSN 2311-0783 (on-line) • Біологічні Студії / Studia Biologica • 2021 • Том 15 / № 1 • С. 3-14 
$A$

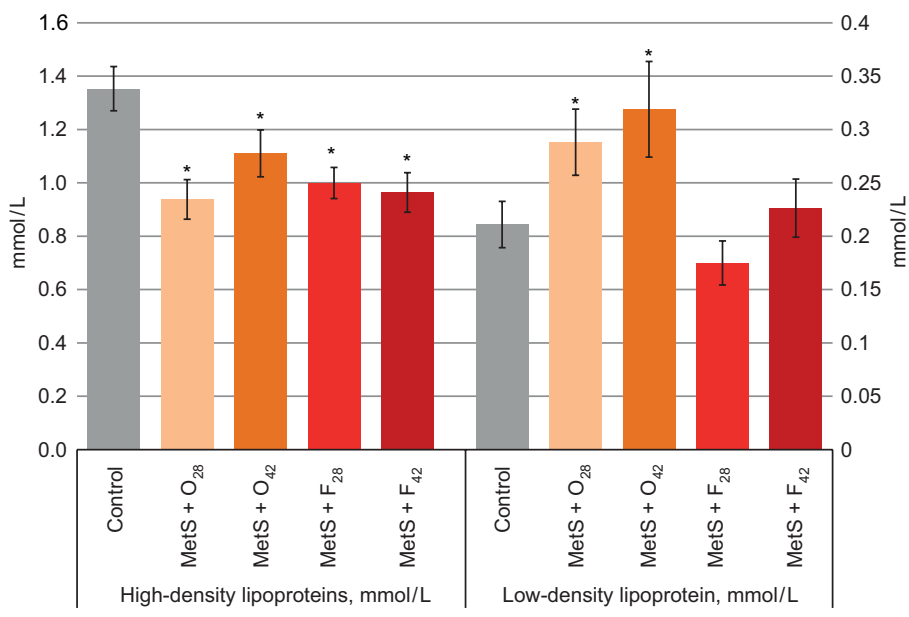

$B$

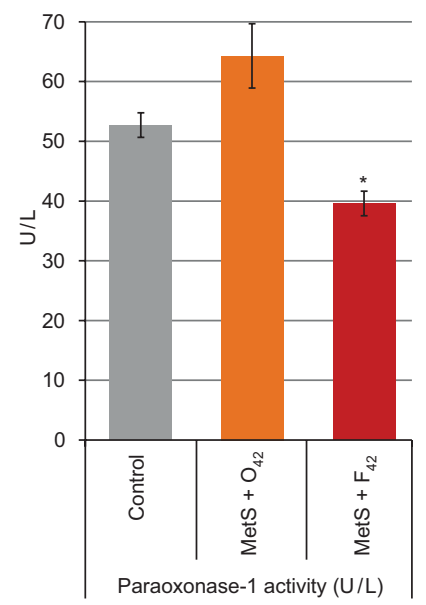

Fig. 5. Changes in the concentration of high-density lipoproteins, low-density lipoproteins $(\boldsymbol{A})$ and paraoxonase-1 activity $(\boldsymbol{B})$ in control animals and under the condition of diet-induced MetS

Рис. 5. Зміна концентрації ліпопротеїнів високої щільності та ліпопротеїнів низької щільності $(\boldsymbol{A})$ й активності параоксонази-1 (B) у нормі та за дієт-індукованого метаболічного синдрому

Small dense LDL are more atherogenic than larger, unmodified LDL. This is due to their higher toxicity to the endothelium and their greater ability to transit through the endothelial membrane. In addition, these lipoproteins are well attached to glycosaminoglycans. Modified LDL are more prone to oxidation and/or more selectively bind to phagocytic receptors on macrophages. Thus, an altered composition of lipoproteins is a risk factor for cardiovascular disease [9].

LDL particles play a significant role in the atherosclerosis development, while HDL are known as atheroprotectors. Atheroprotective characteristics of HDL are due to the reverse cholesterol transport, but also to antioxidative HDL proteins (lecithin: cholesterol acyltransferase, CETP, lipoprotein-associated phospholipase A2, and paraoxonase 1 (PON1)). Among them, PON1 exhibits the strongest antioxidative activity [12]. It seems reasonable to investigate the activity of PON1 in terminal stages of the experiments (MetS $+\mathrm{O}_{42}$, MetS $+\mathrm{F}_{42}$ ), which were characterized by major changes in the lipid profile of the animals' blood plasma. 42 days high-lipid diet was accompanied by an increase in the activity of PON by $22.0 \%$, compared to the control value. The consumption of fructose during the same period was accompanied by a significant decrease in the activity of the studied enzyme by $24.0 \%$ (Fig. 5). It was found that increased LDL led to the inactivation of PON1 level by its interaction with free sulfhydryl group of enzyme. A decreased PON1 activity was accompanied by a high level of lipid peroxidation, and the imbalance between the oxidant and the anti-oxidant impaired a severity of metabolic syndrome [1].

The use of olive oil as a source of additional lipids for the induction of MetS is promising because it allows obtaining the following diagnostic markers of the pathological condition: an impaired glucose tolerance, an increased glycosylated hemoglobin content and an impaired lipid metabolism (see Table). It should be noted that more pronounced changes are found if a high-fat diet is followed for a longer period. 


\section{Comparative table of high-fat and high-lipid diets on changes of diagnostic criteria of metabolic syndrome}

Порівняльна таблиця впливу високовуглеводної та високоліпідної дієт на діагностичні критерії метаболічного синдрому

\begin{tabular}{l|c|c|c|c|c}
\hline \multicolumn{1}{c}{ Diagnostic criteria } & Clinical manifestations & $\mathrm{MetS}+\mathrm{O}_{28}$ & $\mathrm{MetS}+\mathrm{O}_{42}$ & MetS $+\mathrm{F}_{28}$ & MetS $+\mathrm{F}_{42}$ \\
\hline Blood sugar level & $\uparrow$ & $74 \%$ & - & $30 \%$ & $17 \%$ \\
\hline Impaired glucose tolerance & $\uparrow$ AUCglu & - & $37 \%$ & - & $32 \%$ \\
\hline HbA1c content & $\uparrow$ & $37 \%$ & $78 \%$ & $66 \%$ & $221 \%$ \\
\hline Cholesterol concentration & $\uparrow$ & $32 \%$ & $75 \%$ & - & $25 \%$ \\
\hline Concentration of triglycerides & $\uparrow$ & $44 \%$ & $99 \%$ & - & $116 \%$ \\
\hline LDL concentration & $\uparrow$ & $37 \%$ & $51 \%$ & - & - \\
\hline HDL concentration & $\downarrow$ & $31 \%$ & $18 \%$ & $35 \%$ & $40 \%$ \\
\hline PON activity & $\downarrow$ & - & - & - & $24 \%$ \\
\hline
\end{tabular}

High-fat and high-carbohydrate diets are effective inducers of the pathological condition as indicated by the change of almost all diagnostic criteria of metabolic syndrome (see Table). To obtain the animal model of MetS with severe disorders of carbohydrate and lipid metabolism, fructose as well as MUFAs can be used for 42 days.

\section{CONCLUSIONS}

A comparative analysis of the selected approaches to the induction of MetS showed that the consumption of both MUFAs and fructose allows obtaining most of the diagnostic markers of MetS. However, the use of fructose for 42 days, compared to olive oil, causes the most pronounced manifestations of the studied pathology. The use of such a model will determine the biochemical and molecular changes that accompany the development of this pathological condition. It will also facilitate the development and evaluation of the effectiveness of new therapeutic approaches to the treatment of MetS.

\section{COMPLIANCE WITH ETHICAL STANDARDS}

Conflict of Interest: The authors declare that the research was conducted in the absence of any commercial or financial relationships that could be construed as a potential conflict of interest.

Human Rights: This article does not contain any studies with human subjects performed by the any of the authors.

Animal studies: All institutional, national and institutional guidelines for the care and use of laboratory animals were followed.

1. Alaminos-Castillo M.Á., Ho-Plagaro A., García-Serrano S. et al. Increased PON lactonase activity in morbidly obese patients is associated with impaired lipid profile. International Journal of Clinical Practice, 2019; 73(6): e13315.

Crossref • PubMed • Google Scholar

2. Aydin S., Aksoy A., Aydin S., Kalayci M., Yilmaz M., Kuloglu T., Citil C., Catak Z. Today's and yesterday's of pathophysiology: Biochemistry of metabolic syndrome and animal models. Nutrition, 2014; 30(1): 1-9.

Crossref • PubMed • Google Scholar

ISSN 1996-4536 (print) • ISSN 2311-0783 (on-line) • Біологічні Студії / Studia Biologica • 2021 • Том 15 / № 1 • С. 3-14 
3. Buettner R. Parhofer K.G., Woenckhaus M., Wrede C.E., Kunz-Schughart L.A., Schölmerich J., Bollheimer L.C. Defining high-fat-diet rat models: metabolic and molecular effects of different fat types. Journal of Molecular Endocrinology, 2006; 36(3): 485-501.

Crossref $\bullet$ PubMed $\bullet$ Google Scholar

4. Burtis C. A., Ashwood E. R., Bruns D. E. Tietz Textbook of Clinical Chemistry and Molecular Diagnostics. 5rd ed. St. Louis, USA: Elsevier Health Sciences, 2012. 2238 p.

Google Scholar

5. Cameron A.J., Shaw J.E., Zimmet P.Z. The metabolic syndrome: prevalence in worldwide populations. Endocrinology and Metabolism Clinics of North America, 2004; 33: 351-375.

Crossref $\bullet$ PubMed $\bullet$ Google Scholar

6. Carr M., Brunzell J. Abdominal obesity and dyslipidemia in the metabolic syndrome: importance of type 2 diabetes and familial combined hyperlipidemia in coronary artery disease risk. The Journal of Clinical Endocrinology \& Metabolism, 2004; 89(6): 2601-2607.

Crossref $\bullet$ PubMed $\bullet$ Google Scholar

7. Dantoine T.F., Debord J., Charmes J.P., Merle L., Marquet P., Lachatre G., Leroux-Robert C. Decrease of serum paraoxonase activity in chronic renal failure. Journal of the American Society of Nephrology, 1998; 9(11): 2082-2088.

PubMed $\bullet$ Google Scholar

8. Del Moral M.L., Esteban F.J., Torres M.I. et al. High-fat sunflower and olive oil diets affect serum lipid levels in steatotic rat liver differently. J Nutr Sci Vitaminol (Tokyo), 1997; 43(1): 155-160.

Crossref $\bullet$ PubMed $\bullet$ Google Scholar

9. Ivanova E.A., Myasoedova V.A., Melnichenko A.A., Grechko A.V., Orekhov A.N. Small dense lowdensity lipoprotein as biomarker for atherosclerotic diseases. Oxidative Medicine and Cellular Longevity, 2017; 2017: 1273042.

Crossref $\bullet$ PubMed $\bullet$ PMC $\bullet$ Google Scholar

10. James $W$., Rigby N., Leach $R$. The obesity epidemic, metabolic syndrome and future prevention strategies. Eur J Cardiovasc Prev Rehabil, 2004; 11(1): 3-8.

Crossref • PubMed $\bullet$ Google Scholar

11. Kolovou G.D., Anagnostopoulou K.K., Cokkinos D.V. Pathophysiology of dyslipidaemia in the metabolic syndrome. Postgraduate Medical Journal, 2005; 81(956): 358-366.

Crossref • PubMed • PMC • Google Scholar

12. Kotur-Stevuljević J., Vekić J., Stefanović A. et al. Paraoxonase 1 and atherosclerosis-related diseases. BioFactors. 2020; 46(2): 193-205.

Crossref $\bullet$ PubMed $\bullet$ Google Scholar

13. Ong K.T., Mashek M.T., Bu S.Y., Greenberg A.S., Mashek D.G. Adipose triglyceride lipase is a major hepatic lipase that regulates triacylglycerol turnover and fatty acid signaling and partitioning. Hepatology, 2011; 53(1): 116-126.

Crossref $\bullet$ PubMed $\bullet$ PMC $\bullet$ Google Scholar

14. Rifai N., Bachorik P.S., Albers J.J. Lipids, lipoprotein and apolipoprotein. In: Burtis C.A., Ashwood E.R. (Ed.). Tietz textbook of clinical chemistry. 3rd ed. Philadelphia: WB Saunders Company, 1999: 806-861.

Google Scholar

15. Rochlani Y., Pothineni N.V., Kovelamudi S., Mehta J.L. Metabolic syndrome: pathophysiology, management, and modulation by natural compounds. Ther Adv Cardiovasc Dis, 2017; 11(8): 215-225. Crossref • PubMed • PMC • Google Scholar

16. Sánchez-Lozada L.G., Tapia E., Jiménez A. et al. Fructose-induced metabolic syndrome is associated with glomerular hypertension and renal microvascular damage in rats. Am J Physiol Renal Physiol, 2007; 292(1): F423-F429.

Crossref $\bullet$ PubMed $\bullet$ Google Scholar

17. Saudek C.D., Derr R.L., Kalyani R.R., Assessing glycemia in diabetes using self-monitoring blood glucose and hemoglobin A1c. JAMA, 2006; 295: 1688-1697.

Crossref $\bullet$ PubMed $\bullet$ Google Scholar

18. Sweazea K.L., Lekic M., Walker B.R. Comparison of mechanisms involved in impaired vascular reactivity between high sucrose and high fat diets in rats. Nutrition \& Metabolism, 2010; 7(1): 48. Crossref $\bullet$ PubMed $\bullet$ PMC $\bullet$ Google Scholar

19. Wong S.K., Chin K.Y., Suhaimi F.H., Fairus A., Ima-Nirwana S. Animal models of metabolic syndrome: a review. Nutrition \& Metabolism, 2016; 13(1): 65-76.

Crossref • PubMed • PMC • Google Scholar

20. Yeh S.T. Using trapezoidal rule for the area under a curve calculation. Proceedings of the TwentySeventh Annual SAS. User Group International (SUGI) Conference, 2002; 27: 229-237. 
21. Young D.S. Effects of drugs on clinical laboratory tests. Annals of Clinical Biochemistry: International Journal of Laboratory Medicine, 1997; 34(6): 579-581.

Crossref $\bullet$ PubMed $\bullet$ Google Scholar

\title{
ПОРІВНЯННЯ ВИСОКОЛІПІДНОЇ ТА ВИСОКОВУГЛЕВОДНОЇ ДІєТ З МЕТОЮ ОТРИМАННЯЕКСПЕРИМЕНТАЛЬНОЇМОДЕЛІМЕТАБОЛІЧНОГОСИНДРОМУ
}

\author{
T. С. Петрин", М. Р. Нагалєвська, Н. О. Сибірна \\ Львівський національний університет імені Івана Франка \\ вул. Грушевського, 4, Львів 79005, Україна \\ *Кореспондуючий автор e-mail: tetiana.petryn@Inu.edu.ua
}

Вступ. Метаболічний синдром (МС) - це кластер метаболічних аномалій, який включає гіпертонію, центральне ожиріння (відкладання жирової клітковини в абдомінальній діялнці), інсулінорезистентність і атерогенну дисліпідемію. 3 огляду на широку географрічну поширеність і зростання кількості осіб, що страждають на це захворювання, $є$ потреба у розробці тваринних моделей, які б якомога точніше відтворювали розвиток всіх ознак МС людини (інсулінорезистентність, дисліпідемія, ожиріння й артеріальна гіпертензія). Найбільш економічно вигідним і наближеним до реальних причин виникнення МС є використання різних типів дієт.

Матеріали та методи. Дослідження проводили на білих безпородних 6-місячних щурах самцях масою тіла 300-400 г. МС індукували за допомогою високоліпідної та високовуглеводної дієт. Збагачена на ліпіди дієта передбачала споживання тваринами стандартного корму для лабораторних тварин із додатковим вмістом жиру (40 \% маси корму). Джерелом додаткових ліпідів слугувала оливкова олія, що багата на мононенасичені жирні кислоти. Тварини, які перебували на збагаченій на вуглеводи дієті, окрім стандартного корму для лабораторних тварин, споживали 10 \% розчин фруктози замість питної води. Проводили тест толерантності до глюкози та розраховували показник площі під глікемічними кривими. Визначали вміст глікозильованого гемоглобіну та концентрацію глюкози, а також концентрацію ліпопротеїнів низької щільності (ЛПНЩ), ліпопротеїнів високої щільності (ЛПВЩ), холестеролу і тригліцеридів у плазмі крові щурів.

Результати. Розвиток МС, індукованого надмірним споживанням вуглеводів і ліпідів протягом 42 діб, супроводжується порушенням толерантності до глюкози, зростанням вмісту глікозильованого гемоглобіну, тригліцеридів і холестеролу, а також зниженням вмісту ЛПВЩ. Було встановлено зростання концентрації ЛПНЩ і активності параоксонази за індукування патологічного стану надмірним споживанням жирів, тоді як дієта з високим вмістом вуглеводів спричиняє зниженння активності параоксонази.

Висновки. Застосування фрруктози протягом 42 діб зумовлює найбільш виражені прояви досліджуваної патології. Використання такої моделі дасть можливість визначати біохімічні та молекулярні зміни, що супроводжують розвиток цього патологічного стану, і дасть змогу розробити й оцінити ефективність нових терапевтичних підходів у лікуванні МС.

Ключові слова: метаболічний синдром, дієт-індуковані моделі, гіперглікемія, дисліпідемія

Received / Одержано 05 January, 2021
Revision / Доопрацьовано 15 January, 2021
Accepted / Прийнято 17 March, 2021
Published / Опубліковано 31 March, 2021

ISSN 1996-4536 (print) •ISSN 2311-0783 (on-line) • Біологічні Студії / Studia Biologica • 2021 • Том 15 / № 1 • C. 3-14 